\title{
Evaluation of in-Vitro Antioxidant and Antidiarrheal Activities of Peperomia Pellucida Methanol Extracts on Albino Mice
}

\author{
*UWAYA, OD; OMOZUWA, PO; INEGBEDION, RE \\ Department of Science Laboratory Technology, Faculty Of Life Sciences, University Of Benin, Benin City, Nigeria \\ *Corresponding Author Email: dickson.uwaya@uniben.edu; udickson4christ@yahoo.com \\ Tel: (+234) 705-965-0758
}

\begin{abstract}
Peperomia pellucida also known as shiny bush is a common plant wildly distributed in the tropical regions of the world including Nigeria. In ethnomedicine, it is used to treat hemorrhages, fevers, lower cholesterol levels and serves as a cough suppressant, emollient, and diuretic. This study evaluated the in vitro and antidiarrhea activities of Peperomia pellucida. For the in vitro antioxidant assay the following methods were used: 2-diphenyl-2pierylhydrazylhydrate (DPPH) scavenging activity, Superoxide scavenging activity, Hydrogen peroxide scavenging activity, Lipid Peroxidation Assay, Total Antioxidant Capacity, 2,2'-Azinobis (3-Ethylbenzothiazoline-6-Sulphonic Acid) (ABTS) radical scavenging activity and Hydroxyl radical scavenging activity. Antidiarrheal activities were studied using Castor Oil-Induced and Intestinal Transit in Mice models. Methanol and aqueous plant extract of Peperomia pellucida at various concentration demonstrated impressive in vitro antioxidant scavenging activities. The onset of diarrheal $(* * \mathrm{P}<0.01)$ and the $\%$ of charcoal travel $(* \mathrm{P}<0.05)$ in the mice was reduced at $200 \mathrm{mg} / \mathrm{kg}$ compared to the control. Conclusively, this study showed that the aqueous and methanol extract of Peperomia pellucida has in vitro free radical scavenging activities. The plant demonstrated antidiarrheal activities.
\end{abstract}

\section{DOI:https://dx.doi.org/10.4314/jasem.v25i9.21}

Copyright: Copyright $\odot 2021$ Uwaya et al. This is an open access article distributed under the Creative Commons Attribution License (CCL), which permits unrestricted use, distribution, and reproduction in any medium, provided the original work is properly cited.

Dates: Received: 09 May 2021; Revised: 12 August 2021; Accepted: 12 September 2021

Keywords: Antioxidants; Peperomia pellucida; folklore medicine; diarrhea

Plants rich in antioxidants and phytochemicals like tannins and alkaloids are reported to relieve cases of diarrhea (Loganga and Foriers, 2010). Due to the increasing side effects and development of resistance to orthodox medicine, new and safe drug sources are being discovered from plant origin. Peperomia pellucida belongs to the family Piperaceae. It is an herbaceous plant found mainly in America, Africa and Asia. The species develops during rainy periods and thrives in damp, humid soils and under the shade of trees (Majumder et al., 2011). In ethnomedicine, it is used to treat hemorrhages, fevers, lower cholesterol levels and serves as a cough suppressant, emollient, and diuretic (Zubair et al., 2015). Hence, this study is carried out to evaluate the antidiarrhea and in vitro antioxidant activities of Peperomia pellucida.

\section{MATERIALS AND METHODS}

Chemicals: Methanol, distilled water, 2,2-diphenyl-1picrylhydrazyl (DPPH), ascorbic acid, ethylenediaminetetraacetic acid (EDTA), sodium cyanide, nitroblue tetrazolium (NBT), phosphate buffer solution (PBS), riboflavin, hydrogen peroxide, deoxyribose, ascorbate, potassium dihydrogen phosphate, potassium hydroxide, ferric chloride, thiobarbituric acid (TBA), 2,2'-Azinobis (3Ethylbenzothiazoline-6-Sulphonic Acid) (ABTS), potassium persulfate, ferrous sulfate ,acetic acid, trichloroacetic acid (TCA), butanol, conc. tetraoxosulphate (VI) acid, sodium phosphate, ammonium molybdate, sodium chloride, castor oil, activated charcoal and loperamide. All chemicals were of analytical grade and purchased from a reputable chemical store in Benin City.

Authentication of Peperomia pellucida: Fresh plants of Peperomia pellucida were collected from a farmland in Ogbson, Ikpoba Hill, Ikpoba Okha Local Government Area in Benin, Edo State, Nigeria. The plant was identified and authenticated by a taxonomist, Dr. H. A. Akinnibosun in the Department of Plant Biology and Biotechnology, Faculty of Life Sciences, University of Benin.

Aqueous Extraction: Fresh whole plants of Peperomia pellucida were washed with running water to remove dirt. $30 \mathrm{~g}$ of the plant was blended with $100 \mathrm{ml}$ of distilled water using an electric blender. The blended mixture was transferred into a large air tight glass container. The mixture was shaken vigorously intermittently for 24 hours. Thereafter the mixture was 
separated using a cheese cloth. The filtrate was poured into a crucible and concentrated over a water bath at $100{ }^{\circ} \mathrm{C}$. The thick dry extract was then stored in a tight container and kept in a refrigerator for further analysis.

Crude Methanol Extraction: Fresh whole plants of Peperomia pellucida were washed with running water to remove dirt. $30 \mathrm{~g}$ of Peperomia pellucida was blended using an electric blender. The blended mixture was transferred into a large air tight glass container and $100 \mathrm{ml}$ of $100 \%$ methanol was added. The mixture was shaken vigorously intermittently for 72 hours. Thereafter it was separated using a cheese cloth. The filtrate was poured into a crucible and concentrated using a water bath at $40{ }^{\circ} \mathrm{C}$. The thick dry extract was then stored in a tight container and kept in a refrigerator for further analysis.

$70 \%$ Methanol Extraction: Fresh whole plants of Peperomia pellucida were washed with running water to remove dirt. $95 \mathrm{~g}$ plant was blended using an electric blender with $300 \mathrm{ml}$ of distilled water. The blended mixture was transferred into a large air tight glass container containing $700 \mathrm{ml}$ of $100 \%$ methanol. The mixture was shaken vigorously intermittently for 72 hours. Thereafter it was separated using a cheese cloth. The filtrate was poured into a crucible and concentrated using a water bath at $40{ }^{\circ} \mathrm{C}$. The thick dry extract was then stored in a tight container and kept in a refrigerator for further analysis.

Experimental Animals: Albino mice (body weight: 20$30 \mathrm{~g}$ ) of either sex were purchased from the College of Medicine Animal farm, Ambrose Alli University Ekpoma, Edo state, Nigeria. They were housed in the Animal house of Animal and Environmental Biology Department, Faculty of life Sciences, University of Benin, Benin City and acclimatized for 2 weeks. Animals were kept under standard environmental conditions with $12 \mathrm{hr}$ light/dark cycle. They had free access to food (normal grower pellets) and water $\mathrm{ad}$ libitum. The cages were cleaned once daily. All protocols of the National Institutes of Health USA: Public Health policy on Humane use of Laboratory Animals, 2002 and Research Ethics Committee of Department of Science Laboratory Technology were adhered to.

Determination of in vitro Antioxidant Activities of Peperomia pellucida Extracts: 2-diphenyl-2pierylhydrazylhydrate (DPPH) scavenging activity: The scavenging ability of the natural antioxidants of the leaf towards the stable free radical DPPH was measured by the method of the Mensor et al. (2001). The aqueous and methanol plant extracts of Peperomia pellucida at various concentrations were added to $1 \mathrm{ml}$ of the methanol solution of DPPH $(0.3$ $\mathrm{Mm})$. The mixtures were allowed to react at room temperature for 30 minutes. Ascorbic acid served as the standard. After 30 minutes, the discoloration of the purple colour was measured at a wavelength of $518 \mathrm{~nm}$ in a spectrophotometer and radical scavenging activity was calculated:

Scavenging activity $(\%)=\frac{A B c-A B t}{A B c} \times 100$

Where; $\mathrm{ABc}=$ Absorbance of Control; $\mathrm{ABt}=$ Absorbance of control

Superoxide scavenging activity: The aqueous and methanol plant extracts of Peperomia pellucida were added to $0.2 \mathrm{ml}$ of $0.1 \mathrm{~m}$ EDTA, $0.1 \mathrm{ml}$ of $1.5 \mathrm{mM}$ $\mathrm{NBT}$ in $1.5 \mathrm{mg}$ of $\mathrm{NaCN}, 0.05 \mathrm{ml}$ of riboflavin and $2.64 \mathrm{ml}$ of phosphate buffer. The control tube set up where distilled water was added instead of the plant extracts. Optical density, was measured at a wavelength of $560 \mathrm{~nm}$ in a spectrophotometer (Shinde et al., 2006). Superoxide anion scavenging activity was calculated as follows:

Scavenging activity $(\%)=\frac{A B c-A B t}{A B C} \times 100$

Where; $\mathrm{ABc}=$ Absorbance of Control; $\mathrm{ABt}=$ Absorbance of control

Hydrogen Peroxide Scavenging activity: The ability of the Plant extracts to scavenge hydrogen peroxide was assessed by the method of Ruch et al. (1989) modified by Shinde et al. (2006). Various concentrations of the aqueous and methanol plant extracts of Peperomia pellucida were added into $0.6 \mathrm{ml}$ of the solution of $\mathrm{H}_{2} \mathrm{O}_{2}(40 \mathrm{mM})$. In phosphate buffer and the total volume was made up to $3 \mathrm{ml}$. The absorbance of the reaction mixture was recorded at a wavelength of 230 $\mathrm{nm}$ in a spectrophotometer. A blank solution containing phosphate buffer, without $\mathrm{H}_{2} \mathrm{O}_{2}$ was prepared. The extent of $\mathrm{H}_{2} \mathrm{O}_{2}$ scavenging of the plant extracts was calculated as follows:

$\%$ scavenging of hydrogen peroxide $=\frac{A B c-A B t}{A B c} \times 100$

Where; $\mathrm{ABc}=$ Absorbance of Control; $\mathrm{ABt}=$ Absorbance of control

Lipid Peroxidation Assay: A modified thiobarbituric acid-reactive species (TBARS) assay was used to measure the lipid peroxide formed, using egg-yolk homogenates as lipid-rich media (Brand-Williams et al., 1995). Malondialdehyde (MDA), a secondary product of the oxidation of polyunsaturated fatty acids, 
reacts with two molecules of thiobarbituric acid (TBA), yielding a pinkish red chromogen with an absorbance maximum at $532 \mathrm{~nm}$. Egg homogenate $(250 \mu \mathrm{l}, 10 \%$ in distilled water, $\mathrm{v} / \mathrm{v})$ and $50 \mu \mathrm{l}$ of extract were mixed in a test tube and the volume was made up to $500 \mu \mathrm{l}$, by adding distilled water. Finally, $25 \mu \mathrm{l}$ "FeSO 4 " (0.07 M) was added to the above mixture and incubated for $30 \mathrm{~min}$, to induce lipid peroxidation. Thereafter, $750 \mu \mathrm{l}$ of $20 \%$ acetic acid $(\mathrm{pH} 3.5)$ and $750 \mu \mathrm{l}$ of $0.8 \%$ TBA (w/v) (prepared in $1.1 \%$ sodium dodecyl sulphate) and $25 \mu \mathrm{l} 20 \%$ TCA were added, vortexed, and then heated in a boiling water bath for $60 \mathrm{~min}$. After cooling, $3.0 \mathrm{ml}$ of 1butanol was added to each tube and centrifuged at $3000 \mathrm{rpm}$ for $10 \mathrm{~min}$. The absorbance of the organic upper layer was measured against $3 \mathrm{ml}$ butanol at 532 $\mathrm{nm}$. For the blank $50 \mu \mathrm{l}$ of distilled water was used in place of the extract.

Total antioxidant capacity: Phosphomolybdate assay system was used to determine the total antioxidant activity of the methanol extract and various fractions (Umamaheswari, 2008). To a reagent solution; sulphuric acid $(0.6 \mathrm{M})$, sodium phosphate $(2 \mathrm{mM})$ and ammonium molybdate ( $4 \mathrm{mM}) ; 100 \mu \mathrm{l}$ of each sample was added and incubated at $95{ }^{\circ} \mathrm{C}$ in a water bath for 90 min. After cooling to room temperature; absorbance was recorded at $765 \mathrm{~nm}$ against reagent blank. Total antioxidant capacity of the ascorbic acid was also estimated for reference. The total antioxidant capacity was determined by using following formula:

Calculated as \% scavenging activity (I\%) using the following equation:

$\mathrm{I} \%=\frac{\mathrm{Ao}-\mathrm{A} 1}{\mathrm{Ao}} \times 100$

Where; Ao- Absorbance of control; A1- Absorbance in the presence of plant extract.

2,2'- Azinobis (3-Ethylbenzothiazoline-6-Sulphonic Acid) (ABTS) radical scavenging activity: The ABTS $\bullet+$ Stock solution was prepared by reacting ABTS Aqueous solution (7 mM) with $2.45 \mathrm{mM}$ aqueous solution of potassium persulfate in equal amount: the mixture was allowed to stand in the dark at room temperature for 12-16 hours before use. The working solution of ABTS $\bullet+$ was obtained by diluting the stock solution in methanol to give an absorbance of 0.70 at a wavelength of $734 \mathrm{~nm}$. Then, $2.0 \mathrm{ml}$ of ABTS $\bullet+$ solution was mixed with $1 \mathrm{ml}$ of various concentrations of extract of different solvents of Peperomia pellucida. The mixture was then incubated at room temperature for exactly $10 \mathrm{~min}$ in the dark. The control was prepared by mixing $2.0 \mathrm{ml}$ of ABTS
-+ solution with $1 \mathrm{ml}$ of double distilled water. The absorbance was measured against a blank at a wavelength $734 \mathrm{~nm}$ using spectrophotometer. Ascorbic acid was used as the standard. The percentage of scavenging activity of each extract on ABTS $\bullet+$ was calculated as

$\%$ scavenging activity $=\frac{\mathrm{Ao}-\mathrm{A} 1}{\mathrm{Ao}} \times 100($ Jayashree et al., 2015).

Where; Ao- Absorbance of control; A1- Absorbance in the presence of plant extract.

Hydroxyl radical scavenging activity: The extent of hydroxyl radical scavenging activity from the fenton reaction was quantified using 2'-deoxyribose oxidative degradation as described by Elizabeth and Rao (1990), modified by (Shinde et al., 2006). Aqueous and methanol extract of various concentration were added into the reaction mixture contained $0.1 \mathrm{ml}$ of deoxyribose, $0.1 \mathrm{ml}$ of $\mathrm{FeCl}_{3}, 0.1$ $\mathrm{ml}$ of EDTA, $0.1 \mathrm{ml}$ of $\mathrm{H}_{2} \mathrm{O}_{2}, 0.1 \mathrm{ml}$ of ascorbate, 0.1 $\mathrm{ml}$ of $\mathrm{KH}_{2} \mathrm{PO}_{4}-\mathrm{KOH}$ buffer. The mixture was incubated at $37^{\circ} \mathrm{C}$ for 1 hour. At the end of the incubation period, $1.0 \mathrm{ml}$ of thiobutyric acid (TBA) was added and heated at $95^{\circ} \mathrm{C}$ for 20 minutes to develop the colour. After cooling, the colour formation was measured spectrophotometrically at $532 \mathrm{~nm}$ against the blank. The hydroxyl radical scavenging activity was determined as

$\%$ scavenging activity $=\frac{A B c-A B t}{A B C} \times 100$

Where; $\mathrm{ABc}=$ Absorbance of Control; $\mathrm{ABt}=$ Absorbance of control

Antidiarrheal Effect of $70 \%$ Methanol Extract of Peperomia pellucida in Mice: Castor Oil-Induced Diarrheal in Mice: Antidiarrheal activity of methanol plant extract of Peperomia pellucida was tested by using castor oil induced method in mice (Uwaya and Idu, 2020). Loperamide was used as standard drug for this study. Nine mice of either sex (20-25 g) were divided into three groups of three mice each. The animals were fasted for $18 \mathrm{hrs}$ prior to the test.

Group I mice were treated with distilled water (10 $\mathrm{ml} / \mathrm{kg}$ ), which served as control.

Group II (positive control group) received loperamide $(5 \mathrm{mg} / \mathrm{kg})$ which served as positive control

Group III received $200 \mathrm{mg} / \mathrm{kg}$ extracts of Peperomia pellucida

All doses were administered orally. After $1 \mathrm{hr}$, all groups received $0.3 \mathrm{ml}$ of castor oil orally. The 
animals were placed in cages lined with adsorbent papers and observed for $4 \mathrm{hrs}$ for the presence of diarrhea defined as watery (wet), unformed stool. The time for first excretion of feces and the total number of fecal output by the animals were recorded. The adsorbent paper was weighed before and after the test. The activity of each group was expressed as percentage $(\%)$ inhibition of diarrhea. The percentage (\%) inhibition of diarrhea was calculated as follows:

$\%$ inhibition of diarrhea $=\frac{A-B}{A} \times 100$

Where $A$ indicates the mean number of diarrhea feces in control group and $B$ indicates the mean number of diarrhea feces in test group.

Castor Oil Induced Intestinal Transit in Mice: This test was done according to the method of Aye-Than et al. (1989) and Uwaya and Idu. (2020). For this test, selected mice were divided into three groups of three mice in each and fasted overnight. $0.1 \mathrm{ml}$ castor oil was given orally in every mouse of each group to produce diarrhea. After 30 mins:

Group I (control group) received distilled water $(10 \mathrm{ml} / \mathrm{kg})$ orally.

Group II received standard drug (loperamide $5 \mathrm{mg} / \mathrm{kg}$ ) orally

Groups III received $70 \%$ methanol extract of $P$. pellucida $(200 \mathrm{mg} / \mathrm{kg})$ orally

After $1 \mathrm{hr}$, all animals received $10 \mathrm{ml} / \mathrm{kg}$ of charcoal meal (10\% charcoal suspension in $5 \%$ normal saline) orally.

20mins following the charcoal meal administration, all animals were euthanized (sacrificed) via cervical dislocation. The total length and distance covered by the charcoal meal in the intestine, from the pylorus to the caecum was measured and expressed as percentage of the total length of the small intestine from pylorus to the caecum.

Intestinal transit $\%=\frac{L T C}{T L S I} \times 100$

Where;LTC - Length travelled by Charcoal; TLSI Total length of small intestine

Percentage Inhibition of intestinal transit $=\frac{\text { To }-\mathrm{T} 1}{\mathrm{To}} \times$ 100

Where; T0- intestinal transit of control; T1- intestinal transit of extract
Statistical analysis: Results were represented as mean \pm standard error of mean (S.E.M.), and ' $n$ ' represents the numbers of mice per experimental group. Date were subjected to one- way analysis of variance (ANOVA) and differences between samples were determined by Tukey's multiple comparisons test. All data were analyzed using graph pad prism (UK) software version 6 . ${ }^{*} \mathrm{P}<0.05$ indicate significant difference between compared data.

\section{RESULT AND DISCUSSION}

In vitro antioxidant activity result: Figure 1 shows that the methanol and aqueous plant extract of Peperomia pellucida inhibits DPPH radical activity. The results agree with previous studies (Mutee et al., 2010). But aqueous extract at $0.2 \mu \mathrm{g} / \mathrm{ml}$ gave a better scavenging activity of $83.53 \%$ comparable to that of ascorbic acid which at the same concentration gave a scavenging activity of $83.58 \%$. DPPH assay is one of the standard and easy colorimeter methods for evaluating antioxidant activities of pure compounds and also plants like cereals, vegetables, herbs and edible seed oils in food and biochemical industries (Cheng et al. 2006). Therefore, this assay shows the rich antioxidant activities of Peperomia pelucida. Figure 2 shows that the methanol and aqueous plant extract of Peperomia pellucida scavenge Superoxide free radicals. The results agree with previous studies (Merlin and Jyoti, 2018). But aqueous extract at the highest concentration scavenged superoxide free radicals better than ascorbic acid with $91.35 \%$ scavenging activity while ascorbic acid had $66.66 \%$ scavenging activity. Superoxide play an important role in the formation of other reactive oxygen species such as hydrogen peroxide, hydroxyl radical and singlet oxygen, which induce oxidative damage in lipids, protein and Deoxyribonucleic Acid (DNA) (Venkatachalam and Muthukrishnan, 2012). Also, superoxide has been observed to directly start lipid peroxidation (Ilhami et al., 2010). Peperomia pelucida can thus prevent radical chain reaction of superoxide. The methanol and aqueous plant extract of Peperomia pellucida scavenge Hydrogen Peroxide free radicals (Figure 3). But at $0.2 \mu \mathrm{g} / \mathrm{ml}$ methanol extract gave better result (92.75\% scavenging activity) than ascorbic acid (74.56\% scavenging activity). The aqueous and methanol plant extract of Peperomia pellucida scavenge ABTS free radicals (figure 4). But methanol extract at $0.2 \mu \mathrm{g} / \mathrm{ml}$ had $62.77 \%$ scavenging activity better than that of ascorbic acid having 52.96 $\%$. ABTS radical activity is frequently used for estimating the total antioxidant capacity (TAC) of natural products, including crude extracts. The presence of an antioxidant compound inhibits the formation of $\mathrm{ABTS} 4^{+}$which is read spectrometrically (Jian et al., 2009). This shows that the crude extract of 
Peperomia pellucida is rich with antioxidants. Figure 5 shows that the methanol and aqueous plant extract of Peperomia pellucida reduced Lipid peroxidation activity. But methanol extract had the best Lipid peroxidation reduction activity $(66.95 \%)$ at $0.2 \mu \mathrm{g} / \mathrm{ml}$ comparable to that of ascorbic acid having $91.85 \%$ lipid peroxidation reduction activity. Lipid peroxidation is a chain of reactions of oxidative degradation of lipids. This process proceeds by a free radical chain reaction mechanism and has been observed in atherosclerosis, heart failure, cancer and other immunological disorders (Satish and Dilipkumar, 2015). Thus, Peperomia pellucida can prevent such radical induced illness. Figure 6 shows that the methanol and aqueous plant extract of Peperomia pellucida scavenge Hydroxyl free radicals. The results agree with previous studies (Merlin and Jyoti, 2018). But aqueous extract at $0.2 \mu \mathrm{g} / \mathrm{ml}$ had a better scavenging activity of $61.43 \%$ comparable to that of ascorbic acid having $76.05 \%$. Among the oxygen radicals, hydroxyl radical is the most reactive and induces severe damage to the adjacent biomolecules such as all proteins, nucleic acid, and almost any biological molecule it touches.

This damage causes aging, cancer and several diseases. Therefore, the removal of hydroxyl radical is probably one of the most effective defenses of a living body against various diseases (Zhu et al., 2006). Thus, Peperomia pellucida may help prevent diseases associated with free radicals like cancer. The methanol and aqueous plant extract of Peperomia pellucida had the good Total Antioxidant Capacity. But methanol extract had the best Total Antioxidant Capacity $95.63 \%$ comparable to that of ascorbic acid having $97.3 \%$ at $0.2 \mu \mathrm{g} / \mathrm{ml}$. (Figure 7 ).

Reactive oxygen species cause damage to cellular biomolecules such as proteins, nucleic acids, lipids and carbohydrates. Antioxidants interfere with the generation of ROS and also play a crucial role in their inactivation. (Adjimani and Asare, 2015). Under stressful condition, human body produces reactive oxygen species (ROS) which leads to cell damage and health-related problems (Bhadane, Patil and Arts, 2017). like cell aging, cardiovascular diseases, mutagenic changes, and cancerous tumor growth (Ozyurek et al., 2011). Therefore, Peperomia pellucida as an excellent source of antioxidants may help to prevent cases of oxidative stress induced illness like cancer, asthma, diabetes, senile dementia, cardiovascular and inflammatory diseases.

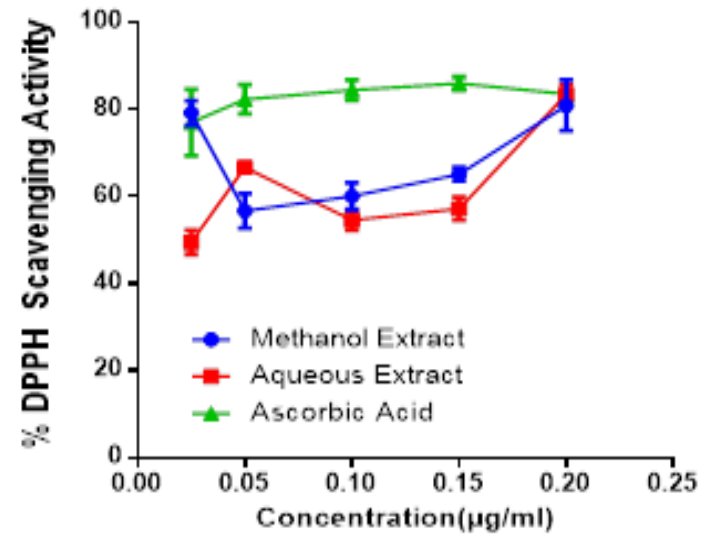

Fig 1: 2, 2-diphenyl-2-picrylhydrazyl hydrate (DPPH) radical scavenging action of methanol and aqueous plant extract of Peperomia pellucida. Values are represented as mean \pm S.E.M., $\mathrm{n}$ $=3$ per group.

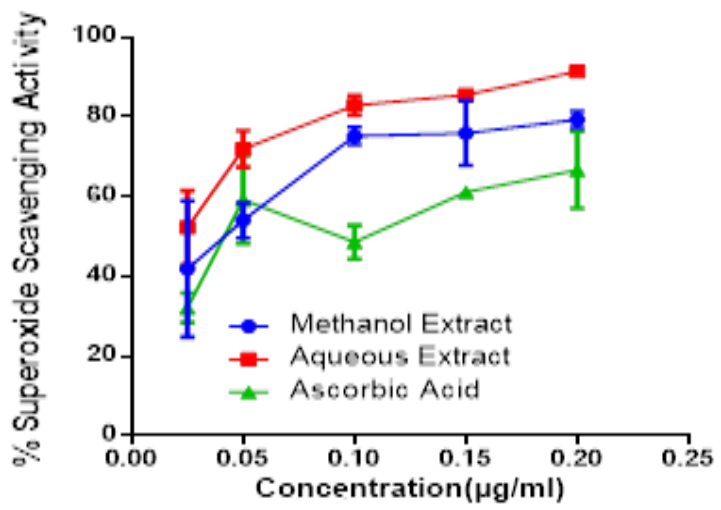

Fig 2: Superoxide radical scavenging action of methanol and aqueous plant extract of Peperomia pellucida. Values are represented as mean \pm S.E.M., $n=3$ per group.

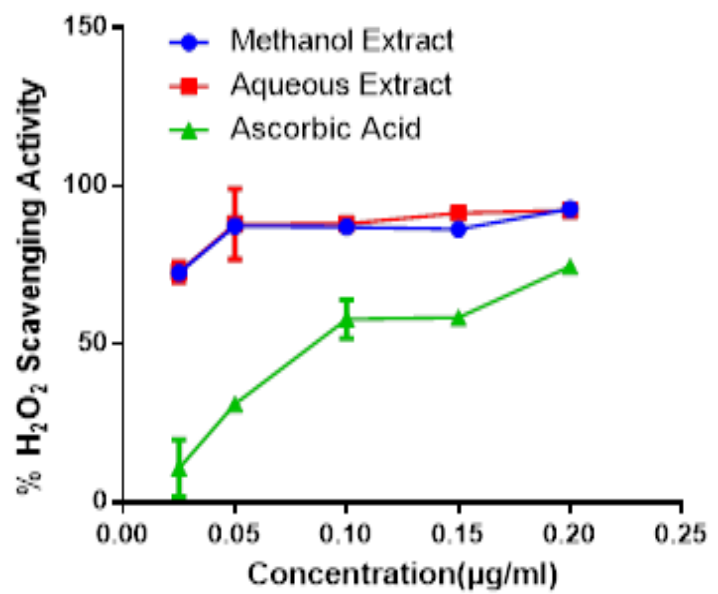

Fig 3: Hydrogen Peroxide radical scavenging action of methanol and aqueous plant extract of Peperomia pellucida. Values are represented as mean \pm S.E.M., $n=3$ per group. 


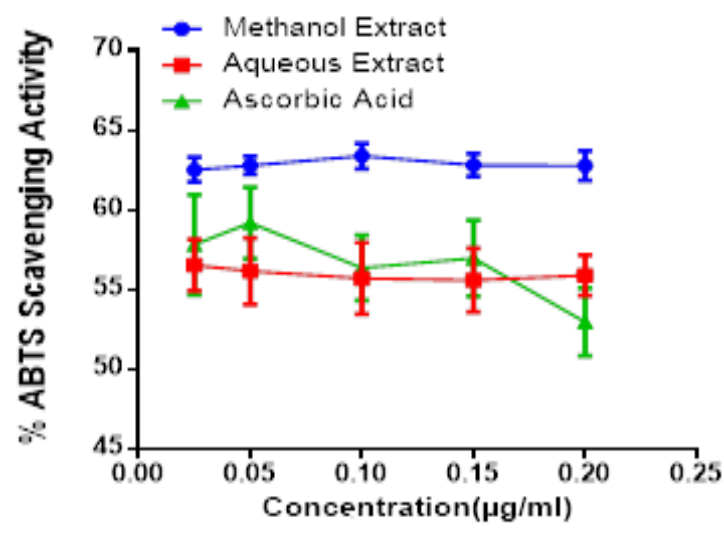

Fig 4 2,2- azino bis-3-ethyl benzthiazoline-6 sulphonic acid (ABTS) radical scavenging action of methanol and aqueous plant extract of Peperomia pellucida. Values are represented as mean \pm

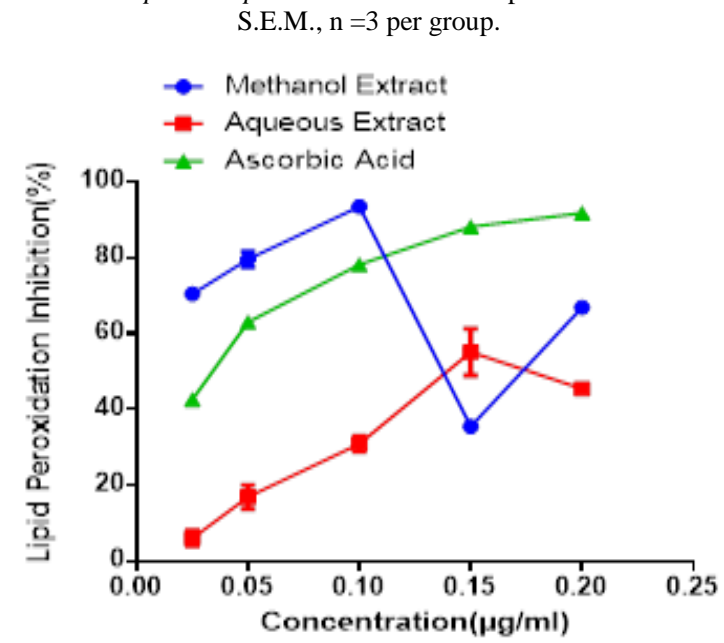

Fig 5: \% Lipid peroxidation inhibition of methanol and aqueous plant extract of Peperomia pellucida. Values are represented as mean \pm S.E.M., $n=3$ per group

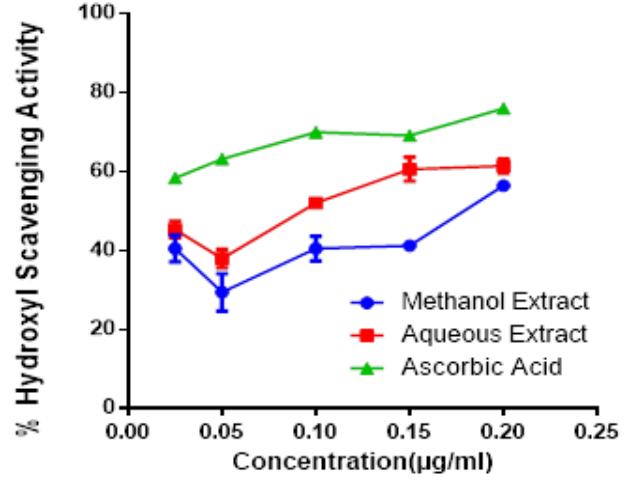

Fig 6: Hydroxyl radical scavenging action of methanol and aqueous plant extract of Peperomia pellucida. Values are represented as mean \pm S.E.M., $\mathrm{n}=3$ per group.

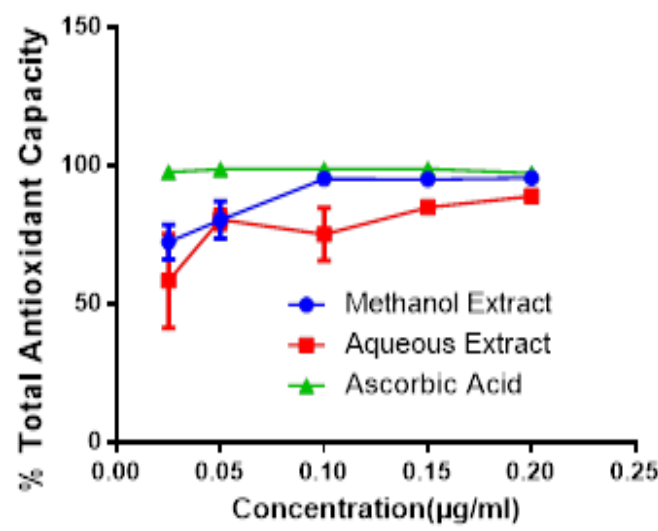

Fig 7: Total antioxidant capacity of methanol and aqueous plant extract of Peperomia pellucida. Values are represented as mean \pm S.E.M., $\mathrm{n}=3$ per group

Table 1: Effect of $70 \%$ Methanol Extract Peperomia pellucida on Castor oil- induced diarrhea in Mice

\begin{tabular}{llllll}
\hline Groups & Treatment & $\begin{array}{l}\text { Weight of } \\
\text { Diarrhea } \\
\text { Faeces (g) }\end{array}$ & $\begin{array}{l}\text { Onset } \\
\text { Diarrhea } \\
\text { (mins) }\end{array}$ & $\begin{array}{l}\text { Total No of } \\
\text { Diarrhea } \\
\text { Faeces }\end{array}$ & $\begin{array}{l}\text { \% Inhibition } \\
\text { of Diarrhea }\end{array}$ \\
\hline CONTROL & $\begin{array}{l}\text { Castor oil }+ \\
\text { Distilled water } \\
\text { (2ml/kg p.o) }\end{array}$ & $0.35 \pm 0.02$ & $4.44 \pm 1.79$ & $7.33 \pm 0.33$ & - \\
STANDARD & $\begin{array}{l}\text { Castor oil+ } \\
\text { Loperamide } \\
\text { (5mg/kg i.p) }\end{array}$ - $0.22 \pm 0.12$ & $171.60 \pm 25.17 * * *$ & $1.67 \pm 0.88^{* * *}$ & $77.27 \%$ \\
& $\begin{array}{l}\text { Castor oil }+ \\
\text { Extract of plant } / \mathrm{kg}\end{array}$ & $0.30 \pm 0.01$ & $27.85 \pm 0.59^{* *}$ & $6.67 \pm 0.88$ & $9.08 \%$ \\
\hline
\end{tabular}

Values were expressed as mean S.E.M. $(n=3)$. Statistically significant difference from control $* * P<0.01, * * * P<0.001$

Castor oil- induced diarrhea result: The $70 \%$ methanol plant extract of Peperomia pellucida at 200 $\mathrm{mg} / \mathrm{kg}$ reduced $(* * \mathrm{P}<0.01)$ the onset of diarrheal in the mice compared to the control as seen in Table 1 . There was no significant reduction in the total no of diarrhea feces and the weight.

Intestinal transition result: The methanol plant extract of Peperomia pellucida at $200 \mathrm{mg} / \mathrm{kg}$ reduced
$(* \mathrm{P}<0.05)$ the $\%$ of charcoal travel in the mice compared to the control as seen in Table 2 . The $70 \%$ methanol plant extract of Peperomia pellucida at 200 $\mathrm{mg} / \mathrm{kg}$ was seen to suppress GIT motility with 28.16 $\%$. Research has shown the presence of reducing sugar, tannin, steroid and alkaloid in Peperomia pellucida (Pulak et al., 2011). Earlier studies showed that anti-dysenteric and antidiarrheal activities of medicinal plants were due to tannins, alkaloids, 
saponins, flavonoids, sterols, tannins and phenolics present in plant extracts (Loganga and Foriers, 2010; Galvez et al., 2013). They are reported to inhibit release of autacoids and prostaglandins, thereby inhibit motility (Loganga and Foriers, 2010; Galvez et al., 2013). The antidiarrheal activity of Peperomia pellucida leaves may be because of its phytochemical constituents. The plant demonstrated a better effect of antidiarrheal activity via suppression in GIT motility. Thus, Peperomia pellucida can help in managing a diarrheal condition.

Table 2: Effect of $70 \%$ Methanol Extract Peperomia pellucida on Intestinal transition in Mice

\begin{tabular}{llllll}
\multicolumn{6}{c}{ Table 2: Effect of $70 \%$ Methanol Extract Peperomia pellucida on Intestinal transition in Mice } \\
\hline Groups & Treatment & $\begin{array}{l}\text { Total Length of } \\
\text { Intestine }(\mathbf{c m})\end{array}$ & $\begin{array}{l}\text { Distance Traveled } \\
\text { By Charcoal }(\mathbf{c m})\end{array}$ & $\begin{array}{l}\text { \% of Charcoal } \\
\text { Travel }\end{array}$ & $\begin{array}{l}\text { \% Suppression } \\
\text { on GIT Motility }\end{array}$ \\
\hline CONTROL & $\begin{array}{l}\text { Castor oil }+ \\
\text { Distilled water } \\
(2 \mathrm{ml} / \mathrm{kg} \text { p.o) }\end{array}$ & $35.59 \pm 0.02$ & $32.92 \pm 4.57$ & $92.50 \pm 3.90$ & - \\
STANDARD & $\begin{array}{l}\text { Castor oil+ } \\
\text { Loperamide } \\
(5 \mathrm{mg} / \mathrm{kg} \text { i.p) }\end{array}$ & $39.43 \pm 4.68$ & $27.83 \pm 4.57$ & $70.58 \pm 5.3 *$ & $29.42 \%$ \\
$200 \mathrm{mg} / \mathrm{kg}$ & $\begin{array}{l}\text { Castor oil }+ \\
\text { Extract of plant }\end{array}$ & $41.72 \pm 3.91$ & $29.97 \pm 0.95$ & $71.83 \pm 2.74 *$ & $28.16 \%$ \\
\hline & & & & \\
\hline
\end{tabular}

Conclusion: This study showed that the aqueous and methanol extract of Peperomia pellucida demonstrated impressive in vitro antioxidant activities. The plant also demonstrated an antidiarrheal activity via suppression on GIT motility.

\section{REFERENCES}

Adjimani, JP; Asare, P (2015). Antioxidant and free radical scavenging activity of iron chelators. Toxicol Rep. 2: 721-728.

Aye-Than, HJ; Wut-hmone; Tha, SJ (1989). Antidiarrhoeal efficacy of some Burmese indigenous drug formulation in experimental diarrhoeal test models. Int. J. Crude Drug Res. 27: 195-200.

Bhadane, B; Patil, R; Arts, RCP (2017). Isolation, purification and characterization of antioxidative steroid derivative from methanolic extract of Carissa carandas (L.) leaves. Biocatal. Agric. Biotechnol 10: 216-223.

Brand-Williams W; Cuvelier, ME; Berset, C (1995). Use of free radical method to evaluate antioxidant activity. Food Sci. Technol 28(1): 25-30.

Cheng, Z; Moore, J; Yu, L (2006). High throughout relative DPPH radical Assay. J. Agric Food Chem. 54: 7429-7436.

DuPont, HL (2014). Acute infectious diarrhea in immunocompetent adults. The New England $J$. Med. 370 (16): 1532-40.

Elizabeth, K; Rao, MNA (1990) Oxygen radical scavenging activity of curcumin. Int $J$ Pharmaceut. 58:237-240.
Galvez, J; Zarzuelo, A; Crespo, ME; Lorento, M; Ocete, MA; Jimenez, J (2013). Antidiarrhoeal activity of Euphorbia hirta extract and isolation of an active flavonoid constituent. Planta Med. 59: 333-336.

Ilhami, G; Zubeyr, H; Elmastas, M; Aboul-enein, HY (2010). Radical scavenging and antioxidant activity of tannic acid. Arab. J. Chem. 3: 43-53.

Jayashree, T; Prabasheela, B; Venkateshwari, R; Nivetha, S; MohanaPriya, P; Vimala, R; Karthik, K (2015). Phytochemical analysis and antioxidant activity of Arachis hypogeal. J. Chem. Pharm. Res. 7(10):116-121.

Jian-Wei, D; Le, C; Yun, X; Jing, Yu; Zhong-Tao Ding (2015). Natural Product Re-evaluation of ABTS $\square+$ Assay for Total Antioxidant Capacity of Natural Products. Commun. 10(12): 2169 - 2172.

Loganga, OA; Vercruysse, A; Foriers, A (2010). Contribution to the ethnobotanical, Phytochemical and pharmacology studies of traditionally used medicinal plant in the treatment of dysentery and diarrhoeal in Lomela area, Democratic Republic of Congo (DRC). J. Ethnopharmacol 71: 411-423.

Majumder, P; Priya, A; Satya, V (2011). Ethnomedicinal, phytochemical and pharmacological review of an amazing medicinal herb Peperomia pellucida (L.) HBK. Res J Pharm Biol Sci. 2:358.

Mensor, LL; Menezes, FS; Leitão, GG; Reis, AS; Tereza, C; Cintia, S; Leitão, S (2001). Screening of Brazilian plant extracts for antioxidant activity 
by the use of DPPH free radical method. Phytother res 15(2): 127-130

Merlin, M; Jyoti, H (2018). Antioxidant and free radical scavenging activities of Peperomia pellucida (L.,): an in vitro study. World J. Pharm. Res 7(17): 1218-1227

Mutee, AF; Salhimi, SM; Yam, MF; Lim, CP; Abdullah, GZ; Ameer, OZ; Abdulkareem, MF; Asmawi, MZ (2010). In vivo anti-inflammatory and in vitro antioxidant activities of Peperomia pellucida. Int. J. Pharmacol 6: 686-690

Ozyurek, M; Guclu, K; Apak, R (2011) The main and modified CUPRAC methods of antioxidant measurement. Trends Analyt Chem 30: 652-664

Perez, M; Boffill, MA; Moron, FJ; Sueiro, ML; Marrero, E; Betancourt, E (2011). Ethnopharmacological and preclinical study of diuretic activity in medicinal and food plants used by Cuban population. Emir. J. Food Agric 23: 214-221.

Pierce, NF; Carpenter, CCJ; Elliot, H Z; Greenough, WB (2011). Effect of prostaglandins, theophylline and Cholera exotoxine upon transmucosal water and electrolyte movement in canine jejunum. Gastroenterol 60: 22-32.

Pulak, M; Priya, A; Satya, V (2011). Ethno-medicinal, Phytochemical and Pharmacological review of an amazing medicinal herb Peperomia pellucida (L.) HBK. Res. J. Pharm. Biol Chem Sci. 2(4): 358364.

Ruch, RJ; Cheng, SJ; Klaunig, JE (1989). Prevention of cytotoxicity and inhibition of intracellular communication by antioxidant catechins isolated from Chinese green tea. Carcinog. 10: 10031008 .
Shinde, V; Kamlesh D; Paradkar, AR; Mahadik, KR; Kadam, SS (2006). Evaluation of in-vitro antioxidant activity of human placental extract. Pharmacologyonline. 3: 172-179

Umamaheswari, M; Chatterjee, TK (2008). In vitro antioxidant activities of the fractions of Coccin niagrandis L. leaf extract. Afr J Tradit Complement Altern Med 5: 61-73.

Uwaya, DO; Idu, M (2020). The Anti-diarrhoea effect of Combretum platypterum (welw) hutch \& dalziel and Combretum racemosum in mice and rats. Science-Tech J. 5(1): 61-74.

Venkatachalam, U; Muthukrishnan, S (2012). Free radical scavenging activity of ethanolic extract of Desmodium gangeticum. J. Acute Med 2: 36-42.

WHO, Diarrheal Disease: Fact Sheet, 2009, http://www.who.int/mediacentre/factsheets /fs330/en/index.html.

Zhu, K; Zhou, H; Qian, H (2006). Antioxidant and free radical-scavenging activities of wheat germ protein hydrolysates (WGPH) prepared with alcalase. Process Biochem 41: 1296-1302.

Zubair, KL; Samiya, JJ; Jalal, U; Mostafizur, R (2015). In vitro investigation of antdiarrhoeal, antimicrobial and thrombolytic activities of aerial parts of Peperomia pellucida. Pharmacologyonline. 3: 5-13. 